\title{
Increasing Added Value of Seaweed Products for Noodle and Jelly Candy in Petemon Surabaya
}

\author{
Author \\ Dwi Yuli Pujiastuti (Orcid ID. 0000-0001-8630-6921), \\ Mochammad Amin Alamsjah (Orcid ID. 0000-0002-1672-499X), \\ Juni Triastuti (Orcid ID. 0000-0003-4378-1946) \\ Corresponden \\ Airlangga University, Jawa Timur, Indonesia \\ dwiyp@fpk.unair.ac.id
}

\begin{abstract}
:
In this PKM program, our partner is residents in Petemon, Surabaya, East Java Province. This community has generated the production of noodle and jelly candy from seaweed. Seaweed processing has a very broad market potential due to the increasing demand and use of seaweed processing products, whether used in the health, pharmaceutical or industrial fields. Development of seaweed with an industrial concept approach that starts from upstream, processing basic products into formulation products with a lot of derivative products, both food and nonfood products. In food ingredients, seaweed can be formulated, among others, into ice cream, pudding, jelly candy or other foods and soft drinks.

Based on interviews and observations in the field, there are 2 main focuses of the problems currently faced by partners, namely: 1) lack of knowledge about seaweed and 2) product diversification of seaweed which have an added value.

Some of the things planned by the PKM team are innovating seaweed to be noodle and jelly candy as well as providing training and mentoring for financial analysis, packaging and marketing. The purpose of this activity is to transfer knowledge of making product diversification of seaweed, develop the creativity of the partner, increase the noodle and jelly candy production and improve the welfare of the partner

This activity was realized with an approach in the form of making a sustainable cooperation program until the end of PKM, creating a family atmosphere between the two and understanding that the problems experienced were a shared problem so that they could be solved together according to the level of responsibility to achieve the expected benefits, namely increased yields, production and productivity and competitiveness, independence and welfare of the community.
\end{abstract}

Keywords: Community Development, Seaweed, Social Welfare, Urban Food Security, Fisheries.

\section{Introduction}

Indonesia as the largest archipelagic and maritime country in the world, has 17,480 large and small islands. Indonesia's marine area reaches 5.9 million $\mathrm{km} 2$, consisting of 3.2 million $\mathrm{km} 2$ of territorial waters and 2.7 million $\mathrm{km} 2$ of Exclusive Economic Zone (EEZ) waters. Indonesia is also blessed with high biodiversity, including marine biological resources covering 2000 species of fish. The wealth of other natural resources is also seen from the extent of the habitat, namely 2.4 million ha of mangrove forest area (30\% of the world's mangrove forests are in Indonesia) and 8.5 million
Received: 12 October 2021. Accepted: 25 December 2021.

ha of coral reefs (17.95\% of the world's coral reefs are in Indonesia). and the largest biodiversity of various types of seaweed (more than 555 species) scattered in various coastal areas (Kadi, 2004).

With so many processed materials that seaweed can produced; it would be nice if the seaweed is processed first rather than directly exported abroad. Due to the potential and diversity of derivative products from seaweed, community empowerment in producing and especially processing seaweed products is very necessary. So that with the formation of the seaweed processing industry into derivative products, it is expected to 
have additional impacts such as the availability of jobs and increased food diversification in Indonesia (Hariyadi, 2014).

Currently, the concern of products produced by most micro, small and medium enterprises in the Petemon Village are well known as otak-otak ikan, meatballs and fish nuggets. In order to increase the added value of other fishery products such as seaweed, it is necessary to make an effort to diversify processed seaweed products not only for food but also for non-food processing. Some members of small and medium enterprises in Petemon Village do not really understand the potential of seaweed to be processed into fishery products. In addition, processing technology, packaging and promotional media are also important for product development from upstream to downstream. With limited knowledge of the types of processing and methods of processing seaweed, this is the reason for the Community Service activities was conducted by the Faculty of Fisheries and Marine, Universitas Airlangga, Surabaya, Indonesia.

\section{Methods}

The implementation of community service activities was attended by residents of RT 03 / RW 14 Petemon Surabaya. Community service activities are carried out by providing counseling to
14 participants due to the covid 19 pandemic. This community service activity includes product diversification of seaweed for making noodle and jelly candy. Before the extension activities were carried out, the media had to prepare first to do the counseling where this activity would take place at the sub-district office by providing an LCD projector. Prior to the presentation of material and product manufacturing practices, the participants will be given a questionnaire to find out about the identity, education level, age and knowledge of participants regarding seaweed products. Furthermore, the related resource person explained about the making of noodle and jelly candy as well as the counseling of financial analysis, packaging and marketing. The training participants will be given time to practice in groups so that it is hoped that the participants will be able to make the processed products themselves after the extension and training for community service ends. In addition, it is important to know the participants' understanding of the packaging and promotion media for the sustainability of the noodle and jelly candy from seaweed. Monitoring and evaluation will be carried out after the counseling and training process with the aim of increasing participants' understanding of the process of making products and their implementation so that they can be sold to the public.

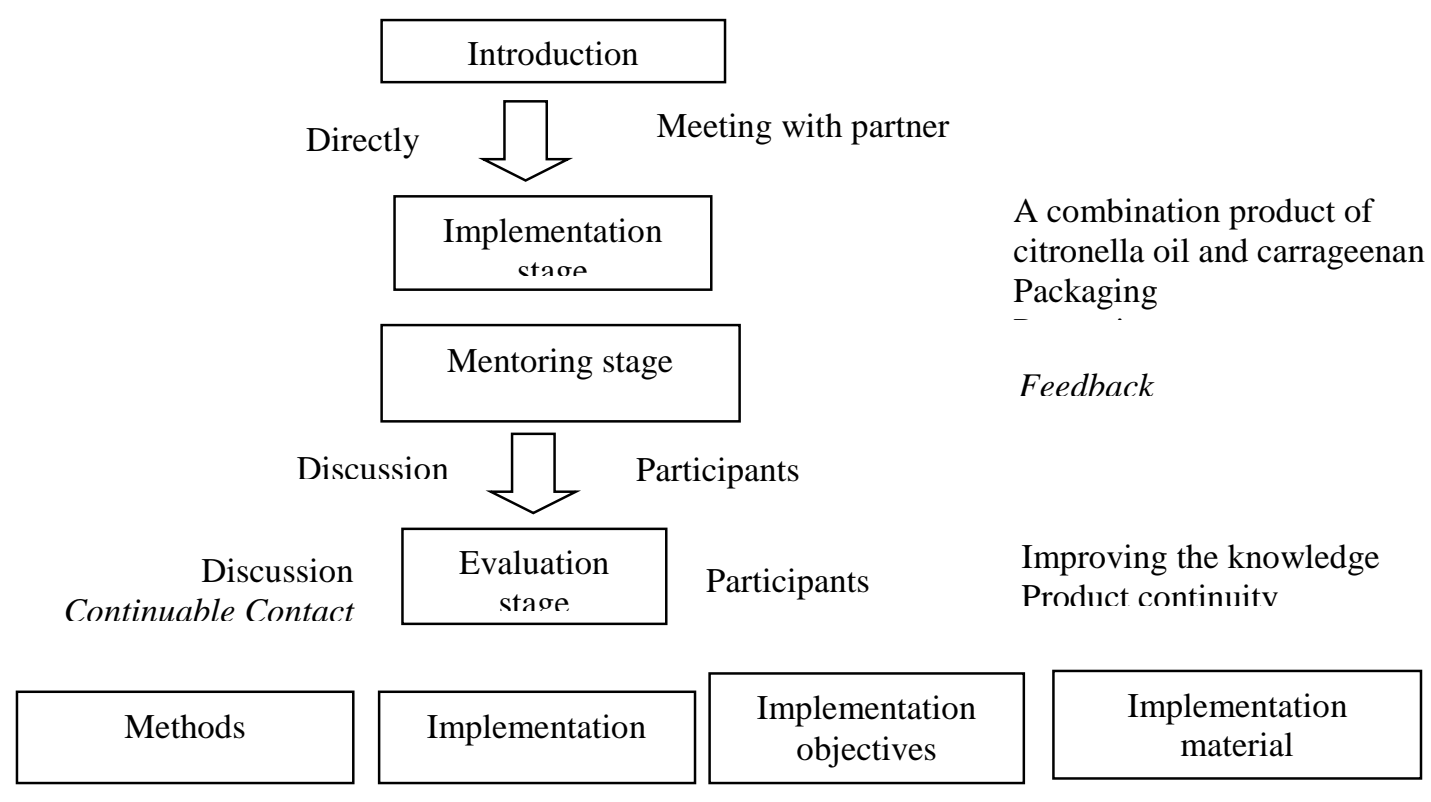

Figure 1. Methods of Implementing Community Service Activities 


\section{Results and Discussions}

This community service activity has been carried out in the RT 03 / RW 14 Petemon, Surabaya. Seaweed can be processed into various benefits such as food, fertilizer, food additives, cosmetic making materials, emulsion materials, and so on. For food manufacture, seaweed can be made into various food and non-food products such as noodles, sticks, jelly candy, soap or raw materials for light bricks (Anggadiredja et al.,2006). Noodles, which are often used as a substitute for rice for some Indonesian people, are in demand from all ages, from children, adults to the elderly. These seaweed jelly noodles and candy are rich in fiber so they can help the digestive system and become alternative products that can be used as entrepreneurial innovations in the future (Suparmi and Sahri, 2009).

The activity started by filling in attendance and distributing the book on seaweed processing that had been compiled by the FPK Community Service team. Furthermore, the activity was opened by remarks from Mrs. Yuni as a neighborhood leader in petemon followed by remarks from Mrs. Dwi as the head of Community Service activities. In his remarks, Mrs. Yuni thanked the team from FPK UNAIR who shared their knowledge about processing seaweed to be noodle and jelly candy. Like a welcome paddle, Mrs. Dwi also expressed her gratitude to the residents of RT 03 / RW 14 Petemon who were pleased to welcome the community service team and prepare for these activities starting from communication, coordination, and implementation.

The activity begins with holding a pre-test at the beginning of the meeting to find out the participants' basic understanding of seaweed product diversification. The number of respondents was 14 participants. The pre-test results showed that only $3(21 \%)$ out of 14 participants had ever made noodle. In general, participants are enthusiastic about making noodle and jelly candy (100\%), but they do not understand the theory, procedures, raw materials, additives, and equipment that must be used to noodle and jelly candy.
The presentation started with introduction of seaweed material and how to make noodle and jelly candy. Noodles is a food product made from wheat flour which is very popular among the people of Indonesia. Noodle products are generally used as a source of energy because they have a fairly high carbohydrate. Raw noodles/fresh noodles, are noodles directly from the dough sheet cutting process with a moisture content of $35 \%$, wet noodles, are raw noodles that have been boiled before being marketed, in boiling water, with a water content of about $52 \%$, dry noodles, are Raw noodles that are directly dried, this type of noodle has a moisture content of about $10 \%$.

Tools and ingredients:

Tools: Noodle Grinder, Basin, Blender, Knife, Frying Pan

Ingredients: 300 grams of Seaweed, 500 grams of Wheat Flour, 2 Egg Yolks, 10 grams of Salt, 100 grams of Water.

Work steps:

1. The seaweed obtained is soaked in water for 24 hours or the time can be extended until the seaweed blooms, the color fades (white) and is odorless. If the color of the seaweed is not white, you can add 2 tablespoons of rice flour when washing (depending on the seaweed you get).

2. After soaking, the seaweed is mashed with a blender and added 100 grams of water until the seaweed becomes mush.

3. Boil the seaweed until cooked.

4. Prepare teringu flour, eggs, salt and stir until it becomes a smooth noodle dough (not sticky)

5. Noodle dough that has been mixed evenly / smooth is made into noodle sheets with a noodle making machine. The noodle dough that is soft is marked by the nonsticky noodle sheets when held by hand and the noodles that are formed do not break easily. Noodle making and printing is done by noodle machine.

6. The printed seaweed noodles are continued with the boiling stage. Boil the noodles by heating water in a pan and adding 2-3 tablespoons of cooking oil. The 
addition of cooking oil aims to prevent the noodles from sticking when boiled.

7. Seaweed noodles can also be stored longer by drying in an oven, the resulting product is dried seaweed noodles.

8. Products can be stored in vacuum packaging for higher shelf life.

The manufacture of jelly candy usually uses a gel-forming material that is reversible, that is, if the gel is heated it will form a sol and when cooled it will form a gel again. In making jelly candy, Eucheuma cottoni seaweed is first washed and soaked in fresh water 10 times the weight of the seaweed. Optimal immersion to get seaweed in the desired condition, namely soaking for. 6-8 hours. On immersion for one day, the cell walls of the seaweed begin to break due to absorbing too much water. This resulted in the release of carrageenan which is the main ingredient of gelling in the manufacture of jelly candy.

The formula for making jelly is the ratio between seaweed and glucose/fructose syrup, which is 1: 2. The amount of glucose syrup that exceeds the optimum amount will produce a gel that is slightly soft, sticky, and has a very sweet taste. This is because the hygroscopic nature tends to reduce the hardness of the jelly candy. If the amount of glucose syrup is less than the optimum amount then the candy becomes less chewy and less sweet. Jelly candy from carrageenan has a fairly chewy texture.

Tools and ingredients:

Tools: blender, panic, plastic basin, stove, stirrer, mold / pan, plastic packaging

Ingredients: Seaweed (200 grams); Water (1000 ml). Sugar (100 grams), vanilla and coloring to taste.

Work steps:

1. Soak the cleaned dried seaweed for 2-3 days.

2. The seaweed is washed again in clean water to make it soft and fresh again.

3. Puree the seaweed using a blender until it becomes mush

4. Cook the seaweed porridge together with water until evenly distributed

5. Add glucose syrup and sugar to the solution, stir until the solution thickens, add dye, essence, sodium benzoate as preservative if needed
6. Put the solution into the mold / pan

7. Leave for 1 hour at room temperature, after which the solution is dried in the sun or with an artificial dryer at $60^{\circ} \mathrm{C}$.

8. Cut and shape the jelly candy according to taste.

The last training is a business analysis to provide an overview of the investment costs, the costs that must be incurred, and the amount of profit that can be obtained from a production business. Economic analysis is important because making noodle and jelly candy is a businessoriented production process. After practice, followed by a discussion session. During the session, the community was enthusiastic and hoped that next year a return visit could be made to Petemon by processing others seaweed products. At the end of the series of activities an evaluation was carried out in the form of a posttest to determine the increase in participant knowledge. The post-test was followed by respondents totaling 14 . The post-test results showed an increase in participants' understanding of the procedure of making noodle and jelly candy as well as the knowledge of seaweed.

\section{Conclusion}

The community service that has been carried out to residents in Petemon, Surabaya, East Java Province has received high enthusiasm which is shown by high enthusiasm and motivation to participate in workshop and training activities. The participants synergize with the community service team of the Faculty of Fisheries and Marine, Universitas Airlangga in innovating product from seaweed into noodle and jelly candy, developing the creativity of the partner as well as improving the social welfare.

\section{References}

Anggadiredja, J. T., A. Zantika, H. Purwoto, dan S. Istiani. 2006. Rumput Laut Pembudidayaan, Pengolahan, dan Pemasaran Komoditas Perikanan Potensial. Penebar Swadaya. Jakarta. 20 hal. 
Hariyadi P. 2014. Pengembangan Industri

Pangan Sebagai Strategi Diversifikasi dan Peningkatan Daya Saing Produk Pangan. Prosiding Seminar Nasional Sains dan Teknologi (SENASTEK). Lembaga Penelitian dan Pengabdian Kepada Masyarakat Universitas Udayana. Denpasar. Bali. hal. 8 - 17.

Kadi, A. 2004. Potensi Rumput Laut Dibeberapa Perairan Pantai Indonesia. Oseana Volume XXIX (4): 25 - 36.

Suparmi dan A. Sahri. 2009. Mengenal Potensi Rumput Laut: Kajian Pemanfaatan Rumput Laut dari Aspek Industri dan Kesehatan. Universitas Diponegoro. Semarang. hal. 96-101. 